Jurnal Riset Kesehatan

http://ejournal.poltekkes-smg.ac.id/ojs/index.php/jrk

\title{
WRITING THERAPY TERHADAP PENURUNAN CEMAS PADA REMAJA KORBAN BULLYING
}

\author{
Galih Mahendra Wekoadi*); Moh. Ridwan ; Angga Sugiarto \\ Jurusan Keperawatan Magelang; Poltekkes Kemenkes Semarang \\ Jalan Perintis Kemerdekaan; Magelang
}

\begin{abstract}
Abstrak
Bullying merupakan salah satu fenomena sosial yang sering terjadi di masyarakat, baik pada anak-anak, remaja, bahkan usia dewasa sekalipun. Kejadian bullying sangat bermacam-macam seperti pukulan fisik, pelecehan verbal, penyebaran gosip, pengucilan maupun penggunaan sosial media untuk mengirimkan berita buruk. Salah satu permasalahan pada korban bullying adalah cemas. Tujuan dari penelitian ini adalah mengetahui efektifitas writing therapy terhadap penurunan cemas pada remaja korban bullying di SMP Negeri 2 Kledung Kabupaten Temanggung. Penelitian ini menggunakan rancangan Quasi Experimental Design dengan metode Non Equivalent Control Grup Design pre-test post-test. Responden dalam penelitian ini sebanyak 40 responden yang diambil dengan metode purposive sampling dan dibagi menjadi 2 yaitu kelompok kontrol dan kelompok intervensi. Pengukuran kecemasan dalam penelitian ini menggunakan skala ukur cemas HARS (Hamilton Anxiety Rating Scale). Intervensi writing therapy dilakukan sebanyak 8 kali pertemuan selama 4 pekan. Setiap pertemuan membutuhkan waktu 35 menit yang terbagi atas 4 sesi. Hasil penelitian menunjukan writing therapy efektif dalam menurunkan cemas $\mathrm{p}=0.000(\mathrm{p}<0.05)$.
\end{abstract}

Kata kunci: Bullying ; Cemas ; Remaja ; Writing Therapy

\begin{abstract}
[WRITING THERAPY ON DECREASE OF FEASIBILITY IN ADOLESCENT BULLYING VICTIMS] Bullying is a social phenomenon that often occurs in the community, both in children, adolescents, even though adulthood. Bullying includes actions such as physical blows, verbal abuse, the spread of gossip, exclusion and the use of social media to transmit bad news. One of the problems in victims of bullying are anxiety and how to overcome them is by using writing therapy. The purpose is this study was to determine the effectiveness of writing therapy to decrease anxiety in young victims of bullying in Junior High School 2 Kledung in Temanggung Regency. This study design was Quasi-Experimental Design method Design Non-Equivalent Control Group pre-test post-test. Respondents in this study were 40 respondents taken by method purposive sampling and were divided into 2 groups: control and intervention group. The anxiety in this study was measured by using a measuring anxiety scale HARS (Hamilton Anxiety Rating Scale). The intervention of writing therapy was done 8 times in 4 weks. Each meeting needed 45 minutes consisting of 4 sessions. The result showed that writing therapy was effective in reducing anxiety $\mathrm{p}=0.001(\mathrm{P}<0.05)$.
\end{abstract}

Keywords: Adolescents ; Anxiety; Bullying ; Writing Therapy

\section{Pendahuluan}

Masa remaja merupakan masa penghubung atau masa peralihan antara masa kanak-kanak

*) Galih Mahendra Wekoadi

E-mail: galihmahendra95@gmail.com dengan masa dewasa. Pada masa ini seseorang akan mudah merasa cemas, terutama saat dihadapkan pada suatu masalah (Purnamarini, Setiawan, Hidayat, 2016). Salah satu contoh permasalahan tersebut adalah bullying. 
Bullying merupakan salah satu fenomena sosial yang sering terjadi di masyarakat, baik pada anak-anak, remaja, bahkan usia dewasa sekalipun. Kejadian bullying yang sering terjadi pun sangat bermacam-macam baik yang bersifat fisik maupun tidak, sebagai contoh adalah pukulan fisik, pelecehan secara verbal, penebaran gosip atau desas-desus palsu, pengucilan maupun penggunaan sosial media untuk mengirimkan berita buruk (Papacosta, Paradeisioti, \& Lazarou ,2014).

Kasus bullying di Indonesia sendiri sudah masuk ke dalam kategori menkhawatirkan dan tingkatannya sudah cukup tinggi. Berdasarkan data dari Kementrian Sosial Republik Indonesia yang sudah menerima sebanyak 117 laporan bullying yang terjadi di Indonesia hingga Juli 2017 (Parawangsa, 2017). Selain itu disebutkan bahwa hasil riset pada tahun 2015 yang dilakukan LSM Plan Internasional dan International Center for Research on Women (IRCW) dalam Komisi Perlindungan Anak (2017) terdapat $84 \%$ anak di Indonesia mengalami bullying di sekolah. Angka tersebut sangat tinggi dibanding negara lain di kawasan Asia.

Bullying di Jawa Tengah berada dalam zona merah. Pada tahun 2015 jumlah kekerasan anak berjumlah 2630 kasus. Dari keseluruhan kasus tersebut didominasi oleh kekerasan seksual sebanyak 846 kasus dan kekerasan fisik sebanyak 823 kasus (Perkumpulan Keluarga Berencana Indonesia, Jawa Tengah, 2016). Angka Bullying di Kabupaten Temanggung yang terekspos berjumlah 4 kasus kekerasan anak dengan penjabaran 3 kasus kekerasan seksual dan 1 kasus kekerasan emosional (Dinas Kesehatan Kabupaten Temanggung, 2017).

Bullying di SMP Negeri 2 Kledung sangat tinggi, dari hasil studi pendahuluan yang telah dilakukan terhadap siswa-siswi kelas VIII sejumlah 92 responden hanya 1 anak saja yang belum pernah menjadi korban bullying di sekolah tersebut dan sejumlah 91 siswa pernah menjadi korban bullying. Bullying di SMP Negeri 2 Kledung Kabupaten Temanggung sangat beragam. Bentuk bullying di sekolah tersebut adalah bullying secara fisik, verbal, non verbal tidak langsung, dan non verbal langsung. Bullying secara verbal menjadi jenis bullying yang mendominasi di SMP Negeri 2 Kledung dengan jumlah 76 kasus. Disusul dengan bullying secara fisik dengan jumlah 69 kasus, bullying non verbal langsung sebanyak 41 kasus, dan bullying non verbal tidak langsung sebanyak 41 kasus. Dari 91 responden yang pernah mengalami perlakuan bullying, didapatkan sejumlah 65 anak mengalami gangguan kecemasan.

Undang-Undang No. 23 Tahun 2002 tentang perlindungan anak pasal 54 menyebutkan bahwa anak di dalam lingkungan sekolah wajib dilindungi dari tindakan kekerasan yang dilakukan oleh guru, pengelola sekolah atau teman-temannya (Undang-Undang Nomor 23 Tahun 2002 tentang Perlindungan Anak, 2013). Untuk itu perlu dilakukan penanganan masalah cemas akibat bullying pada remaja di SMP Negeri 2 Kledung tersebut.

Salah satu terapi yang dapat digunakan untuk mengatasi masalah cemas adalah dengan menggunakan writing therapy. Writing therapy dapat meningkatkan pemahaman mengenai diri sendiri maupun seseorang dalam menghadapi depresi, distres, kecemasan, adiksi, ketakutan terhadap penyakit, dan kehilangan serta perubahan dalam kehidupannya (Susanti \& Supriyanti, 2013). Writing therapy dipilih sebagai salah satu metode yang tepat karena terapi tersebut akan memotivasi, menstabilkan emosi, dan dapat meningkatkan pemahaman mengenai diri sendiri seperti kekuatan dan kelemahan diri pada korban bullying yang mengalami kecemasan (Prasetyono, 2012).

Tujuan dari penelitian ini adalah untuk mengetahui efektivitas writing therapy terhadap penurunan cemas pada remaja korban bullying di SMP Negeri 2 Kledung Kabupaten Temanggung.

\section{Metode}

Penelitian ini menggunakan rancangan penelitian Quasi Experiment Design dan menggunakan metode Non Equivalent Control Grup Design pre-test post-test. Dalam penelitian ini peneliti menggunakan kuisioner bullying yang dikembangkan dari Riauskina, Djuwita dan Soesetio dalam Wiyani, (2014) serta skala ukur cemas HARS (Hamilton Anxiety Rating Scale). Intervensi writing therapy dalam penelitian ini dilakukan sebanyak 8 kali pertemuan dalam 4 pekan. Setiap pertemuan membutuhkan waktu 35 menit yang terbagi atas 4 sesi. Sesi dalam writing therapy ini adalah : Recognition atau Initial Write, Examination atau Writing Exercise, Juxtaposition atau Feedback, dan Aplication to the self. Populasi dalam penelitian ini adalah remaja korban bullying yang mengalami kecemasan di SMP Negeri 2 Kledung Kabupaten Temanggung. Sample dalam penelitian ini diambil menggunakan teknik purposive sampling dan didapatkan jumlah semple 
penelitian sebanyak 40 responden yang terbagi menjadi 2 kelompok yaitu kelompok intervensi dan kelompok kontrol.

Pengolahan data data dalam penelitian ini melalui proses editing, coding, entry data, Tabullating dan pembahasan atau diskusi hasil penelitian. Analisa data dalam penelitian ini menggunakan analisa Univariat dan analisa bivariat. Analisa univariat meliputi standart deviasi, median, modus, minimum, maksimum dan mean. Hasil tersebut akan dapat mengambarkan nilai skor kecemasan pada remaja korban bullying di SMP Negeri 2 Kledung Kabupaten Temanggung. Analisa Bivariat dalam penelitian ini menggunakan uji paired t-test dan uji wilcoxon untuk uji perbedaan pre-test dan post-test, sedangkan untuk membandingkan antara kelompok kontrol dan kelompok intervensi uji beda menggunakan uji independent t-test dan uji mann whitney. Analisa signifikan yang digunakan antara dua variabel dalam penelitian ini adalah $95 \%$ dengan nilai $\mathrm{a}=$ 0,05 .

Etika penelitian yang diberikan dalam penelitian ini diantaranya adalah persetujuan responden (Informed consent), kerahasiaan (confidentiality), dan Ethical Clereance.

\section{Hasil dan Pembahasan}

1. Karakteristik Responden

Tabel 1. Karakteristik Responden Berdasar Jenis Kelamin

\begin{tabular}{lcc}
\multicolumn{1}{c}{ Jenis Kelamin } & $\begin{array}{c}\text { Kelompok Intervensi } \\
\mathbf{n = 2 0}\end{array}$ & $\begin{array}{c}\text { Kelompok Kontrol } \\
\mathbf{n}=\mathbf{2 0}\end{array}$ \\
\hline Laki-Laki & 4 & 8 \\
Perempuan & 16 & 12 \\
\hline Jumlah & 20 & 20 \\
\hline
\end{tabular}

Tabel 2. Distribusi Responden Berdasar Umur

\begin{tabular}{lcccccc}
\hline Kelompok & Mean & Median & Modus & $\begin{array}{c}\text { Standar } \\
\text { Deviasi }\end{array}$ & Maksimum & Minimum \\
\hline $\begin{array}{l}\text { Intervensi } \\
\mathbf{n}=\mathbf{2 0}\end{array}$ & 14 & 14 & 14 & 0.649 & 13 & 16 \\
$\begin{array}{l}\text { Kontrol } \\
\mathbf{n}=\mathbf{2 0}\end{array}$ & 14.9 & 15 & 14 & 1.309 & 13 & 18 \\
\hline
\end{tabular}

Tabe1 3. Distribusi Skor Kecemasan Pre-Test dan Post-Test Kelompok Intervensi

\begin{tabular}{lcccccc}
\hline Kelompok & Mean & Median & Modus & $\begin{array}{l}\text { Standar } \\
\text { Deviasi }\end{array}$ & Minimum & Maksimum \\
\hline $\begin{array}{l}\text { Pre-Test } \\
\mathbf{n}=\mathbf{2 0}\end{array}$ & 20.7 & 19.5 & $19 \& 22$ & 4.342 & 14 & 28 \\
$\begin{array}{l}\text { Post-Test } \\
\mathbf{n}=\mathbf{2 0}\end{array}$ & 13.25 & 14 & 16 & 5.33 & 6 & 26
\end{tabular}

Tabel 4 Distribusi Skor Kecemasan Pre-Test dan Post-Test Kelompok Kontrol

\begin{tabular}{lcccccc}
\hline Kelompok & Mean & Median & Modus & $\begin{array}{l}\text { Standar } \\
\text { Deviasi }\end{array}$ & Minimum & Maksimum \\
\hline $\begin{array}{l}\text { Pre-Test } \\
\mathbf{n}=\mathbf{2 0}\end{array}$ & 21.95 & 20 & $20 \& 25$ & 4.310 & 16 & 30 \\
$\begin{array}{l}\text { Post-Test } \\
\mathbf{n = 2 0}\end{array}$ & 20.5 & 25 & $25 \& 26$ & 7.373 & 9 & 46 \\
\hline
\end{tabular}

2. Uji hipotesis

a. Pendistribusian Data Kelompok

Tabel 5 Distribusi Data

\begin{tabular}{clccc}
\hline \multirow{2}{*}{ Kelompok } & & \multicolumn{3}{c}{ Shapiro-Wilk } \\
\cline { 3 - 5 } & & Statistic & df & Sig \\
\hline \multirow{2}{*}{ Intervensi } & Pre-Test & .946 & 20 & .311 \\
& Post-Test & .944 & 20 & .281 \\
\multirow{2}{*}{ Kontrol } & Pre-Test & .918 & 20 & .090 \\
& Post-Test & .897 & 20 & .037 \\
Diff & Pre-Test & .970 & 20 & .756 \\
& Post-Test & .919 & 20 & .095 \\
\hline
\end{tabular}

Copyright $(\odot) 2018$, Jurnal Riset Kesehatan, ISSN 2252-5068 
b. Uji Beda Pre-Test dan Post-Test

Tabel 6 Uji Beda Pre-Test dan Post-Test Kelompok Intervensi

\begin{tabular}{|c|c|c|c|c|}
\hline & Rerata & Selisih & IK $95 \%$ & Nilai p \\
\hline Pre-Test & 20.70 & \multirow{2}{*}{7.45} & \multirow{2}{*}{$9.65-5.24$} & \multirow{2}{*}{.000} \\
\hline Post-Test & 13.25 & & & \\
\hline
\end{tabular}

Tabel 7 Uji Beda Pre-Test dan Post-Test Kelompok Kontrol

\begin{tabular}{lcc}
\hline & $\begin{array}{c}\text { Median } \\
\text { (Minimum - Maksimum) }\end{array}$ & Nilai p \\
\hline Pre-Test & $20(16-30)$ & .050 \\
Post-Test & $25(9-46)$ & .050 \\
\hline
\end{tabular}

c. Uji Beda Kelompok Kontrol dan Kelompok Intervensi

Tabel 8 Uji Beda Pre-Test Kelompok Intervensi dan Kelompok Kontrol

\begin{tabular}{|c|c|c|c|}
\hline & Rerata & Nilai $p$ & Perbedaan Rerata (IK 95\%) \\
\hline Kelompok Intervensi & $20.70(4.34)$ & \multirow{2}{*}{.367} & \multirow[b]{2}{*}{$1.25(4.01-1.51)$} \\
\hline Kelompok Kontrol & $21.95(4.31)$ & & \\
\hline
\end{tabular}

Tabel 9 Uji Beda Post-Test Kelompok Intervensi dan Kelompok Kontrol

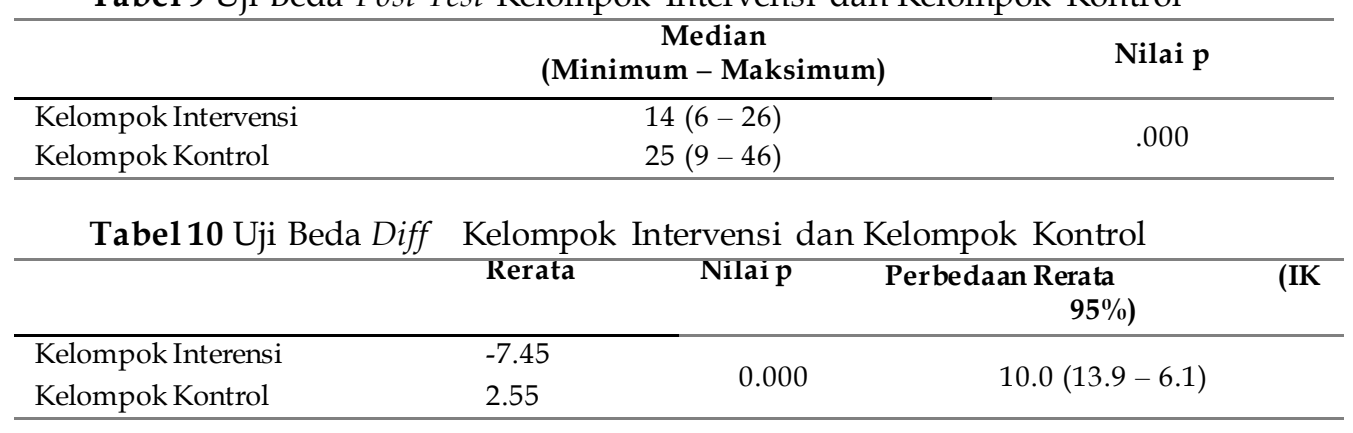

\section{Karakteristik Responden}

Berdasarkan hasil penelitian yang telah dilakukan responden perempuan mendominasi dalam penelitian ini. Data hasil penelitian menunjukan bahwa pada kelompok intervensi ada 16 responden berjenis kelamin perempuan. Sementara pada kelompok kontrol 12 responden berjenis kelamin perempuan.

Hasil penelitian lainnya menunjukan bahwa perempuan memiliki sifat sekunderis pada perasaan bukan berdasarkan intelektualnya. Perempuan lebih emosional daripada laki-laki karena perempuan sangat peka dan mudah meluapkan perasaan, sementara itu laki-laki lebih bersikap objektif dan rasional sehingga mampu berfikir dan tidak mengedepankan emosionalnya. Karena itu perempuan lebih cepat bereaksi dengan hati, bingung, takut, dan cemas (Putri, Kristiyawati \& Arif, 2014).

Hasil penelitian menunjukan remaja dengan umur 14 tahun dan 15 tahun cukup mendominasi. Pada kelompok intervensi remaja dengan umur
14 tahun sebanyak 15 responden. Sementara itu pada kelompok kontrol remaja yang berumur 14 tahun sebanyak 7 responden dan remaja yang berumur 15 tahun sebanyak 7 responden.

Salah satu faktor yang mempengaruhi kecemasan adalah usia, semakin berta mbah usia seseorang maka semakin baik tingkat kematangan emosi seseorang serta kemampuan dalam menghadapi berbagai permasalahan (Darmawati, 2017). Menurut Putri, Nauli dan Novayelinda (2015) perilaku bullying akan mulai berkurang sejalan dengan pertumbuhan usia, rentang usia 12 - 16 tahun diyakini lebih rentan perilaku bullying, sebab di usia ini perilaku bullying anak akan mulai muncul. Pada masa remaja ini seseorang akan mudah merasa cemas, terutama saat dihadapkan pada suatu masalah (Purnamarini, Setiawan, Hidayat, 2016).

Skor Kecemasan Pre-Test dan Post-Test 
Hasil penelitian didapatkan bahwa sebelum dilakukan writing therapy pada kelompok intervensi $(n=20)$ semuanya berada pada rentang cemas berdasarkan hasil ukur skala cemas HARS (Hamilton Anxiety Rating Scale) dengan nilai rata-rata yang didapat sebesar 20.7. Skor yang paling banyak muncul adalah 19 dan 22 dengan jumlah responden 3 orang. Skor cemas tertinggi adalah 28 dengan 2 responden dan skor cemas terendah 14 dengan 1 responden. Sementara pada kelompok kontrol didapatkan nilai rata-rata pre-test 21.95. Skor terbanyak adalah 20 dan 25 dengan masing-masing memiliki 4 responden. Nilai tertinggi dari pre-test adalah 30 dengan 1 responden dan nilai terendahnya adalah 16 dengan 1 responden.

Dari dua data pre-test pada kelompok intervensi dan kelompok kontrol tersebut, dilakukan uji beda dengan tujuan mengetahui perbedaan rerata kelompok kontrol dan kelompok intervensi. Uji beda dilakukan dengan menggunakan independent $\mathrm{t}$-test. Uji tersebut dipilih karena data pre-test pada kedua kelompok tersebut terdistribusi normal $(p>0.05)$. Hasil yang didapatkan adalah $\mathrm{p}=0.367(\mathrm{p}>$ 0.05 ) yang berarti tidak ada perbedaan yang bermakna antara kelompok intervensi dan kelompok kontrol atau baseline memiliki nilai sama.

Baseline sendiri merupakan pengukuran dari perilaku atau aspek subjek sebelum perlakuan dilakukan yang memungkinkan dilakukannya pembanding dan pengukuran terhadap efek intervensi atau sebagai landasan pembanding untuk menilai suatu keefektifan suatu perlakuan. Baseline phase atau fase keadaan awal memiliki 2 fungsi yaitu fungsi diskriptif yang merupakan fungsi untuk menggambarkan keberadaan level performasi subjek yang dieksperimenkan secara alamiah tanpa adanya perlakuan dan fungsi prediktif yang berfungsi untuk meramalkan perilaku subjek jika tidak ada intervensi (Hidayati, 2014)

Setelah dilakukan writing therapy pada kelompok intervensi terjadi penurunan jumlah responden yang mengalami kecemasan, dari 20 responden 9 responden tidak mengalami kecemasan dengan skor yang tersebar dalam beberapa skor < 14 dan sisanya mengalami kecemasan. Nilai rata-rata skor kecemasan post-test pada kelompok ini adalah 13.25 dan skor 16 merupakan skor yang mendominasi dengan 4 responden. Skor kecemasan terendah pada data post-test kelompok intervensi adalah 6 dengan 3 responden dan skor tertinggi 26 dengan 1 responden. Sementara itu pada kelompok kontrol didapatkan rata-rata post-test 20.5 dan skor cemas 25 dan 26 merupakan skor yang mendominasi dengan 3 responden. Skor tertinggi yang diperoleh pada post-test kelompok kontrol ini adalah 46 dengan 1 responden dan skor terendah yang diperoleh adalah 9 dengan 1 responden.

Dari dua data post-test pada kelompok intervensi dan kelompok kontrol dilakukan uji beda dengan tujuan mengetahui perbedaan rerata. Uji dilakukan menggunakan mann-whitney test. Uji beda tersebut dipilih karena data post-test pada kelompok kontrol tidak terdistribusi normal $\mathrm{p}=0.037(\mathrm{p}<0.05)$. Hasil uji beda menunjukan $p=0.000(p<0.05)$ yang berarti terdapat perbedaan yang bermakna antara post-test kelompok intervensi dan post-test kelompok kontrol.

Menulis dapat mengklasifikasikan pikiran dan perasaan diri sendiri dengan lebih baik serta dapat menurunkan tekanan pada seseorang. Menulis dapat membantu melepaskan intensitas perasaan (emosi, sedih, pengalaman menyakitkan dan lain-lain) serta dapat memecahkan masalah dengan efektif karena umumnya masalah dipecahkan dengan otak kiri, akan tetapi kadang hanya ditemukan dengan otak kanan yang bersifat kreatif dan intuitif. Selain itu dengan menulis seseorang dapat mengenali sisi kepribadian positif dirinya yang sebelumnya tersembunyi atau dihalangi mineset yang keliru (Saifudin \& Kholidin, 2015). Penelitian serupa juga pernah dilakukan oleh Dewi \& Budiono (2013) yang didapatkan hasil bahwa writing therapy dapat digunakan sebagai sarana untuk meluapkan emosi dan menurunkan cemas.

\section{Pembahasan Hipotesis}

Pada uji beda pre-test dan post-test pada kelompok intervensi didapatkan $\mathrm{p}=0.000(\mathrm{p}<$ 0.05 ) yang berarti terdapat perbedaan yang bermakna antara pre-test dan post-test pada kelompok intervensi tersebut. Sementara itu pada kelompok kontrol yang tidak diberikan perlakuan, uji beda pre-test dan post-test didapatkan hasil $\mathrm{p}=0.05$ dengan kesimpulan bahwa tidak terdapat perbedaan yang bermakna antara pre-test dan post-test pada kelompok kontrol.

Uji beda antara kelompok intervensi dan kelompok kontrol juga dilakukan pada diff pre-test dan post-test kedua kelompok tersebut, dan didapatkan hasil $\mathrm{p}=0.000(\mathrm{p}<0.05)$ 
dengan kesimpulan terdapat perbedaan yang bermakna antara kelompok intervensi dan kelompok kontrol setelah pemberian writing therapy pada kelompok intervensi. Berdasarkan hasil tersebut, maka hipotesis kerja (Ha) dalam penelitian ini diterima yang berarti writing therapy efektif dalam menurunkan cemas pada remaja korban bullying di SMP Negeri 2 Kledung Kabupaten Temanggung.

Hasil penelitian yang dilakukan sesuai hasil penelitian sebelumnya, penelitian sebelumnya yang dilakukan Dewi \& Budiono (2013) menyebutkan bahwa writing therapy efektif dalam menurunkan kecemasan, dengan writing therapy seseorang dapat meluapkan emosi dan dapat menurunkan cemas. Pendapat lain menyebutkan bahwa dengan menulis akan memberikan informasi, membuka cakrawala baru, mengeluhkan keprihatinan, membangkitkan keindahan, menghibur, membangkitkan semangat dan daya pikir serta kritik sosial atau bentuk proses (Adhani, 2012). Penelitian yang dilakukan ini juga memiliki hasil yang sama dengan penelitian yang dilakukan oleh Susanti \& Supriyantini (2013) yang menunjukan bahwa dengan menulis efektif dalam menurunkan tingkat kecemasan. Hasil yang sama juga didapatkan pada penelitian yang dilakukan Purnamarini, Setiawan \& Hidayat (2016) yang menunjukan expressive writing berpengaruh pada penurunan kecemasan pada siswa kelas XI SMA Negeri 59 Jakarta. Hasil penelitian yang sama juga didapat pada penelitian yang dilakukan Saifudin \& Kholidin (2015) yang menunjukan bahwa terapi menulis ekspresif berpengaruh terhadap penurunan tingkat kecemasan. Rohmadani (2017) dalam penelitiannya menunjukan bahwa writing therapy efektif dalam menangani masalah kecemasan.

Menulis adalah suatu bentuk eksplorasi dan ekspresi area pikiran, emosi, dan spiritual yang dapat dijadikan sebagai sarana untuk berkomunikasi dengan diri sendiri dan mengembangkan suatu pemikiran serta kesadaran akan suatu peristiwa (Saifudin \& Kholidin, 2015). Mengungkapkan emosi yang kuat, baik melalui berbicara dengan orang lain maupun menulis memiliki efek positif yang signifikan dalam kesehatan (Melathy \& Astuti, 2014). Tindakan menulis merupakan kerja otak kiri, yang bersifat analitis dan rasional. Ketika otak kiri sedang aktif, otak kanan menjadi bebas untuk berkreasi, menjadi intuitit dan merasakan, sehingga menulis memindahkan hambatan mental dan memungkinkan orang untuk menggunakan kekuatan otak untuk memahami diri sendiri, orang lain dan dunia sekitar dengan baik (Saifudin \& Kholidin, 2015). Menurut Susanti \& Supriyantini (2013) melalui menulis, seseorang dapat mengekspresikan diri hingga memperoleh pemahaman yang lebih baik dan mentransformasikan pemahaman tersebut untuk menjadi emosi yang baik untuk menyelesaikan masalah. Selain itu dapat membantu merekonstruksi kognitif dan pengorganisasian peristiwa trauma yang dialami seseorang. Menulis pengalaman emosional juga dapat mempengaruhi kesehatan fisik, yang menunjukan adanya penurunan aktifitas sistem saraf otonom dan kardiovaskuler seperti yang dialami individu dalam proses rileks (Susanti \& Supriyantini, 2013). Menulis dapat dijadikan sebagai intervensi jangka pendek bagi orang dengan gejala stres, cemas, dan depresi (Rohmadani, 2017), karena w riting therapy dapat digunakan sebagai sarana untuk meluapkan emosi dan dapat menurunkan cemas (Dewi \& Budiono, 2013)

\section{Limitasi Penelitian}

Pada penelitian ini peneliti tidak melakukan randomisasi dalam pengambilan sample.

\section{Simpulan dan Saran}

Responden perempuan merupakan mayoritas dalam penelitian ini. Pada kelompok intervensi perempuan memiliki jumlah responden 16 anak dan pada kelompok kontrol memiliki responden 12 anak. Berdasarkan umur, remaja dengan umur 14 dan 15 tahun merupakan remaja korban bullying yang mengalami kecemasan lebih banyak.

Writing therapy terbukti efektif dalam menurunkan cemas pada remaja korban bullying di SMP Negeri 2 Kledung Kabupaten Temanggung. Hasil uji beda pre-test dan post-test pada kelompok intervensi menunjukan $\mathrm{p}=0.000(\mathrm{p}<0.05)$ yang berarti terdapat perbedaan yang bermakna antara pre-test dan post-test setelah diberikan intervensi dibandingkan kelompok kontrol yang menunjukan hasil $\mathrm{p}=0.05$. Hasil tersebut diperkuat dengan uji beda post-test antara kelompok kontrol dan kelompok intervensi yang menunjukan $\mathrm{p}=0.000(\mathrm{p}<0.05)$ yang berarti terdapat perbedaan yang bermakna antara kelompok kontrol dan kelompok intervensi. Hasil serupa juga didapatkan pada uji beda diff pada kelompok kontrol dan kelompok intervensi 
yang menunjukan hasil $\mathrm{p}=0.000(\mathrm{p}<0.05)$ yang berarti terdapat perbedaan yang bermakna antara kelompok kontrol dan kelompok intervensi.

Penurunan skor kecemasan pada remaja korban bullying kelompok intervensi mengalami penurunan lebih banyak dibandingkan dengan kelompok kontrol.

Bagi peneliti selanjutnya bila melakukan penelitian serupa atau efektifitas writing therapy dengan menggunakan rancangan quasi experimental ataupun true experimental, alangkah baiknya dalam pengambilan sample, peneliti melakukan randomisasi dalam pengambilan sempel.

Writing therapy dapat digunakan sebagai sarana mengatasi cemas pada remaja korban bullying. Writing therapy juga dapat dilakukan dirumah dan tidak harus dilakukan di sekolah untuk mengatasi kecemasan pada remaja korban bullying.

Writing therapy dapat diterapkan di lingkungan sekolah untuk mengatasi masalah kecemasan pada remaja korban bullying. Diharapkan dengan tidak adanya perasaan cemas pada remaja atau siswa-siswi korban bullying, prestasi belajar anak akan meningkat. Writing therapy tersebut dapat dilakukan setiap jam pelajaran Bimbingan Konseling (BK) agar masalah cemas pada remaja korban bullying tidak sampai terbawa sampai rumah dan terselesaikan di sekolah sehingga dengan writing therapy tersebut masalah psikososial maupun masalah kejiwaan pada remaja korban bullying dapat dicegah secara dini.

Bagi institusi kesehatan upaya promotif dan preventif dengan menggunakan writing therapy dalam kesehatan jiwa hendaknya lebih diupayakan dan diutamakan di kalangan komunitas..

\section{Ucapan Terima Kasih}

Terima kasih kepada Direktur Poltekkes Kemenkes Semarang, DIPA Poltekkes Kemenkes Semarang yang telah mendanai penelitian ini, Tim penyusun pengabmas dan semua pihak yang terlibat dalam penyusunan artikel penelitian ini.

\section{Daftar Pustaka}

Adhani, A. (2012). Menulis Sebagai Salah Satu Upaya Terapis : Studi Kasus Penanganan Korban Kekerasan dalam Rumah Tangga. Widya Warta (1). ISSN 0854 - 1981.
Balary, A. C. (2014). The Impact of Direct and Indirect Bullying on The Mental and Physical of Health of Italian Youngsters. Aggressive Behavior. 30:343 - 355.

Darmawati, Z. R. (2017). Pengaruh Terapi Psikoedukasi Terhadap Tingkat Kecemasan Pasien Hemodialisa di Rumah Sakit Tentara $d r$ Soedjono Magelang. Skripsi tidak dipublikasi. Magelang : Prodi D IV Keperawatan Magelang.

Dewi, C. C. \& Budiono. (2013). Pengaruh Terapi Menulis Terhadap Penurunan Tingkat Kecemasan Pasien Kanker Servis Stadium Lanjut. Midwifery Science Journal. 1 (1) : 172 -182 .

Dinas Kesehatan Kabupaten Temanggung. (2017). Data Dasar Kesehatan Anak. (http://www. Sipt. Temanggungkab.go.id diakses 11 Januari 2018 pukul 15. 45)

Greene, B. M. (2003). Counseling and Climate Change as Treatment Modalities for Bullying in School. International Journal for the Advancement of Counselling. 25 (4) : 293 -302 .

Hidayati, T. N. (2014). Efektifitas Metode Pembelajaran Terapi Picture Exchange Communication System (PECS) Terhadap Komunikasi Verbal Ada Anak Autis. Skripsi tidak dipublikasikan. Surabaya : Program Studi Psikologi, Fakultas Psikologi dan Kesehatan Universitas Islam Negri Sunan Ampel.

Komisi Perlindungan Anak Indonesia. (2017). Data Kekerasan Anak di Sekolah, (http:// www.Kpai.go.id, diakses 9 Januari 2018 pukul 15.30).

Melathy, C.E. \& Astuti, T. P. (2014). Pengaruh Menulis Ekspresif Terhadap Kecemasan Pada Penderita Diabetes Mellitus Tipe II. Jurnal Empati. 3 (4) : 106 - 118.

Papacosta, E. S, Paradeisioti, A \& Lazarou ,Ch. (2014). Bullying Phenomena and Preventive Programs in Cyprus's School System. International Journal of Mental Health Promotion, 16 (1), 67 - 80.

Parawangsa, K. I. (22 Juli 2017). 117 Laporan Bullying Diterima Tepas Kemensos RI Hingga Juli 2017. Tribun Jogja.

Perkumpulan Keluarga Berencana Indonesia. (2016). Kekerasan Anak, (http://www.pkbijateng.or.id diakses 11 Januari 2018 pukul 15.38)

Prasetyono, D. S. (2012). Bedah Lengkap Grafologi. Yogyakarta : Diva Press.

Purnamarini, D. P. A, Setiawan, T. I.\& Hidayat, D. R. (2016). Pengaruh Terapi Expressive 
Writing Terhadap Penurunan Kecemasan saat Ujian Sekolah. Jurnal Bimbingan Konseling, 5(1); $36-42$.

Putri, H. N, Nauli, F. A \& Novayelinda, R. (2015). Faktor-Faktor yang Berhubungan dengan Perilaku Bullying pada Remaja. JUM. 2(2) : 1149 - 1159.

Putri, D. S., Kristiyawati, S. P., \& Arif, S. (2014). Pengaruh Terapi Humor Terhadap Penurunan Kecemasan Pada Pasien Pre Operasi dengan General Anestesi di RS Tegalrejo Semarang. Jurnal Ilmu Keperawatan dan Kebidanan. 1 (6).

Rivers, I \& Smith, P. K. (1994). Types of Bullying Behaviour and Their Correlates. Aggressive Behavior. $20: 359-368$.

Rohmadani, Z. V. (2017). Relaksasi dan Terapi Menulis Ekspresif Sebagai Penanganan Kecemasan pada Difabel Daksa. Journal of Health Studies 1 (1) : $18-27$.

Saifudin, M. \& Kholidin, M. N. (2015). Pengaruh Terapi Menulis Ekspresif Terhadap
Tingkat Kecemasan Siswa Kelas XII MA Ruhul Amin Yayasan SPMMA (Sumber Pendidikan Mental Agama Allah) Turi di Desa Turi Kecamatan Turi Kabupaten Lamongan. Jurnal Media Komunikasi Ilmu Kesehatan. 7 (3) : ISSN 1979 - 9128.

Surya, M. (2001). Kapita Selekta Kependidikan SD. Jakarta : Universitas Terbuka.

Susanti, R. \& Supriyantini, S (2013). Pengaruh Expressive Writing Therapy Terhadap Penurunan Tingkat Kecemasan Berbicara di Muka Umum Pada Mahasiswa. Jurnal Psikologi. 9 (2); 120 - 129.

Undang - undang Nomor 23 Tahun 2002 tentang Perlindungan Anak. 2013. Jakarta: Admin Komisi Perlindungan Anak

Wiyani, N. A. (2014). Save Our Children From School Bullying. Jogjakarta : Ar - Ruzz Media. 